\title{
THE ACTION FOR BREACH OF PROMISE OF MARRIAGE IN EARLY COLONIAL NEW ZEALAND: FITZGERALD $V$ CLIFFORD (1846)
}

\author{
Megan Simpson*
}

In 1846, the first breach of promise of marriage case was heard by the Supreme Court of New Zealand. Unlike many other breach of promise cases heard throughout the Empire during the nineteenth century, this case was not publicly reported. Rather, it is a case that exists only within the pages of Justice Chapman's judicial notebook, absent from the newspaper court reports of the time. This action was relatively rare in the colony but the testimonies of witnesses examined enable us to gain an insight into matters of class, courtship, family, reputation and social protocols in the mid-nineteenth century. This paper considers the legal history of the action in New Zealand from 1842-1875, focussing on the case of Fitzgerald v Clifford (1846) to explore how private matters of courtship and romance became matters of legal and sometimes public debate.

Matters of romance and courtship are often absent from narratives of early New Zealand history. The importance of marriage is often emphasised in discussions of gender and family in the early colony but the precursor to this institution often remains unexplored. While marriage was a central part of most settlers' lives, the process of making it to the altar was not always simple. Courtship could be a fraught time for couples and, for some, the uncertain terms of intimacy could result in heartache and broken promises. The action of breach of promise of marriage was a legal remedy available to individuals whose engagements had been broken off without mutual agreement. It provided an outlet for the jilted lover to gain damages for the failure to fulfil a promise. The case of Fitzgerald $v$ Clifford was the first action of breach of promise to be heard in colonial New Zealand. ${ }^{1}$

* $\quad$ Research Fellow, New Zealand Lost Cases Project, Faculty of Law, Victoria University of Wellington. My thanks to Shaunnagh Dorsett, Charlotte MacDonald, Siobhan Simpson and Sam Ritchie. This case was recovered by the Lost Cases project, which is funded by the New Zealand Law Foundation. All online citations were correct at time of writing.

1 Emily Fitzgerald v Charles Clifford, Supreme Court Wellington, 11-12 September 1846 per Chapman J. All direct discussion and quotation from the case comes from this archival source: "Notebook entitled 'Civil trials No. 7'", Hocken Library, Dunedin (HL), 1846-7, MS-0411/008, 120 Pages (unnumbered). 
While it was a relatively rare action, with only ten cases heard by the courts in New Zealand before 1875 , these cases enable us to gain an insight into matters of class, courtship, marriage, gender and social protocols. ${ }^{2}$ The cases also highlight how the courts were used by settlers to resolve not just matters of financial dispute but also private matters of courtship and family, which were increasingly brought before the courts as a key part of maintaining order and respectability in the colony.

The case involved Emily Fitzgerald and Charles Clifford, a couple who had originally met in 1842 on board the passenger ship, George Fyfe. Emily's brother, Thomas, had initially become friends with Clifford. ${ }^{3}$ Emily and Thomas were travelling to New Zealand to join their brother John, who had arrived in Wellington in $1840 .{ }^{4}$ Over the two day trial, the Supreme Court heard an account of the couple's four year courtship, from the happy beginnings though to the quarrels that erupted over Clifford's secret fiancée. Emily took an action for breach of promise of marriage after Clifford ended the pair's four year relationship. He had agreed to honour a previous engagement with Mary Ann Hercy, a woman living in England who was soon to travel to New Zealand.

The Fitzgeralds and Clifford were part of the colonial elite in early Wellington. ${ }^{5}$ Wellington was a very small settlement during the 1840 s and these families were part of a group that had established itself in the new settlement, creating close connections between the administrators, the judiciary, land owners, newspaper proprietors and those with commercial interests. ${ }^{6}$ There were very close associations within this group. Many of these individuals socialised with each other; they shared commercial interests and sat on juries, which were responsible for adjudicating cases often involving their associates. ${ }^{7}$ In some respects this case was an unusual. First, it was the only case to

2 This study has used the period 1842-1875 to frame its discussion: the date of the first Supreme Court sitting in New Zealand through until 1875, the year that evidence reform for breach of promise was introduced in New Zealand. See footnote 30 .

3 The trio arrived in Wellington on 7 November 1842: New Zealand Colonist and Port Nicholson Advertiser (Wellington, 8 November 1842) at 2.

4 John Fitzgerald arrived in Wellington on 31 January 1840 on board the "Oriental": New Zealand Gazette and Wellington Spectator (Wellington, 2 May 1840) at 3.

5 John Patrick Fitzgerald (1815-97) Coroner and Surgeon Wellington; Thomas Fitzgerald (1824-1888) Surveyor Wellington and later became a Member of Parliament for Hawkes Bay; Emily Tyser (nee Fitzgerald) (1814?-1861) had three children and died in the Hawkes Bay in 1861. Charles Clifford (18131893) Member of the Legislative Council, Justice of the Peace and later Speaker of the House of Representatives.

6 In 1842 the population of Wellington was 3801; by 1846 this had only grown to 3977. Colin George Fredrick Simpkin Statistics of New Zealand for the Crown Colony Period 1840-1852 (Department of Economics, Auckland University College, Auckland, 1954) at 8.

7 This closeness posed a problem for Chapman J. He made a concerted effort to distance himself from associating too much with this group, but he was on close terms with some members. Clifford was a close acquaintance of Chapman, who wrote to his father in 1845 that he was to make Clifford a trustee for an 
involve two members of the colonial elite in the period before $1875 .{ }^{8}$ This was significant because protocols around courtship could differ across class. Evidence in Fitzgerald $v$ Clifford differs from the wider body of New Zealand cases, as it contains more emphasis on social protocols and courtship etiquette rather than focussing on financial repercussions caused by the failed engagement. Second and more importantly, it was an unreported case in the fullest sense. It was a case largely absent from local newspapers and consequently has become a forgotten part of early New Zealand case law.

During the 1840s newspapers played a central part in colonial court reporting. New Zealand did not introduce official court reporting until 1883 and as a result the only consistent case records for this period are the reports printed in local newspapers. The quarterly proceedings of the Supreme Court were regularly and consistently reported in the Wellington newspapers. Newspaper editors dedicated much space to the coverage of Supreme Court trials, often including full verbatim accounts of each case. The coverage of a trial depended on the resources of the newspaper and the contemporary importance of the case. Minor civil matters received very little coverage, while cases of importance to the mercantile community or high profile criminal cases were published in full. An action for breach of promise of marriage would have been of high interest to readers in the settlement. The scandal of such trials was appealing to readers but the reporting of the trial could have substantial implications for the reputation of each party.

Patrick Day has argued that newspapers in colonial New Zealand expressed the views of the ruling class alone. ${ }^{9}$ This point is reinforced by examining the coverage of this particular case. Both the Fitzgerald brothers (John and Thomas) and Clifford had close associations with the settlement's

investment for his sons: [HS Chapman] "Letters Vol 1" Alexander Turnbull Library, Wellington (ATL) 1843-1846, qMS-0418, at 196.

8 This paper uses the term "colonial elite" to refer to the small group of people who had political power and influence in the colony. This term differs from those commonly used in New Zealand historiography, which generally use terms such as "upper class" or "gentry" to describe this group. See James Belich Making Peoples: A History of the New Zealanders (Penguin Books, Auckland, 1996) at 321-326; Jim McAloon No Idle Rich: The Wealthy in Canterbury and Otago 1840-1914 (University of Otago Press, Dunedin, 2002) at 22-23. Traditional English definitions of class do not fit the colonial setting. The colonial elite, which formed in the new settlement of Wellington, included people with local wealth, power and influence. However, these individuals were predominantly from the English middle class, who were able to achieve upward social mobility by holding positions of power and responsibility in the new colony. These individuals would not have attained the same level of power and influence within English society. While class was more fluid in New Zealand, there is strong evidence that an elite governing class was established in the colony but this needs to be discussed within colonial terms, not by relying on the traditional terminology of the English class system.

9 Patrick Day The Making of the New Zealand Press: A Study of the Organizational and Political Concerns of New Zealand Newspaper Controllers (Victoria University Press, Wellington, 1990) at 237. 
newspaper proprietors. ${ }^{10}$ This had implications for how the case was reported by the local papers (or not reported as was the case). There was a clearly a concerted effort to make sure that the case remained out of the newspapers, which ensured that Clifford's affairs would not be broadcast throughout the colony and possibly abroad. The New Zealand Spectator and Cook's Strait Guardian (NZSCSG) reported the Supreme Court civil cases heard on the 8th and the 19th of September (directly before and directly after) but the Fitzgerald case, which was heard by the Court on the $11^{\text {th }}$ and 12th September was absent from the newspaper. The Wellington Independent also did not report on the case. The one newspaper that did report the case was the New Zealander, an Auckland paper, which had a small note printed in its Wellington column before the case was heard by the Court. ${ }^{11}$ Presumably the proprietors of the paper were not concerned with rustling feathers in the south. The complete absence of a case report in the court coverage by local newspapers was very unusual. Often minor civil matters received very little coverage but the complete absence of large trial from the press was unprecedented. By excluding this case from the regular court reports, the local newspaper proprietors protected Clifford's interests. As a consequence this case exists only within the pages of Chapman J's judicial notebook, absent from the newspaper court reports of the time. ${ }^{12}$

The trial for breach of promise of marriage would have been quite a spectacle in the early settlement. At that time, marriage was an occasional event in the colony, with only twenty-one marriages taking place in Wellington during $1845 .{ }^{13}$ Very few engagements would have ended in such a public manner. There was a strong emphasis on the need for both men and women to marry in colonial society. A woman's livelihood depended on marriage. Her sole responsibility was to marry and build a family; this was an emphasis constantly reinforced by the church, family, and popular opinion. It was important that a woman's reputation was intact and her eligibility protected. Involvement in a failed engagement could threaten this, as could a high profile breach of promise of marriage trial. For men, marriage was also an important stage. It was thought that women were a

10 Robert Stokes the editor of the New Zealand Spectator and Cook's Strait Guardian [NZSCSG] worked with Clifford in establishing the paper in 1843. The Fitzgerald brothers would also have been known to Stokes, as all three worked for the New Zealand Company on their arrival in Wellington. Isaac Featherston, the editor of the Wellington Independent had informally worked with Clifford during the 1840s to address local affairs: AH McLintock (ed) "Stokes, Robert" and "Featherston, Dr Isaac Earl" in An Encyclopaedia of New Zealand (Government Printers, Wellington, 1966) <www.teara.govt.nz/en/1966>.

11 New Zealander (Auckland, 12 September 1846) at 3. It seems likely that this report eventuated because of colonial gossip. The dispute involving such high profile figures would have been of interest to readers, despite local attempts to restrict publicity. No follow up report was made after the trial was concluded.

12 The coverage of the case in Chapman J's judicial notebook is very detailed, covering one and twenty hundred pages. This case is much larger than other civil cases heard during the same period. Chapman J's notes only contain verbatim coverage of the witnesses' testimony, with no personal commentary or notes.

13 No marriage statistics are available for 1846. Simpkin, above n 6, at 30. 
'civilising' force and as a result it was essential for them to marry. ${ }^{14}$ Marriage was at the heart of the colonial project, as it was thought that by establishing solid, moral families it would help in creating a successful, thriving colony. ${ }^{15}$ Bettina Bradbury has argued that marriage was "a signifier of stability, respectability and successful colonisation". ${ }^{16}$ Marriage was key part of a broader social and moral ideology found across the Empire, it was central to the success of the colony.

While the action for breach of promise was centred on damages for a breach of contract, it was also about maintaining concepts of respectability and order. It was not just courtship that could be scrutinised by the courts. The institution of marriage was a highly regulated practice in the colony and came before the courts in a multitude of ways. Legitimate marriage was a central tenet to life in the colony. Marriage legislation was amended twice during the 1840s to ensure that marriages were regulated, solemnised, and publicised in a consistent and official manner. ${ }^{17}$ Violations of these ordinances, along with marital desertion, bigamy and property disputes all brought private matters of marriage and family into the public realm of the courts. However, these types of proceedings all focussed on technical aspects of the law rather than personal characteristics and circumstances, which were central to the action of breach of promise.

Breach of promise is an action that has received little attention from New Zealand historians. ${ }^{18}$ This is not unexpected as the action is now considered a quirk of legal history. Given the action was not abolished in New Zealand until 1975, it is surprising that it has quickly become a forgotten aspect of law. ${ }^{19}$ However, there is a large body of historiography on nineteenth century breach of promise of marriage actions in other common law jurisdictions. ${ }^{20}$ The body of cases heard in

14 Jock Phillips A Mans Country? The Image of the Pakeha Male: A History (Penguin Books, Auckland, 1996) at 51 .

15 Edmond Gibbon Wakefield emphasised Victorian ideals of the family in his theory of colonisation. See Angela Wanhalla "Family, Community and Gender" in Giselle Byrnes (ed) The New Oxford History of New Zealand (Oxford University Press, Melbourne, 2009) 458.

16 Bettina Bradbury "Colonial Comparisons: Rethinking Marriage, Civilisation and Nation in NineteenthCentury White Settler Societies" in Phillip Buckner and R Douglas Francis (eds) Rediscovering the British World (University of Calgary Press, Calgary, 2006) 135 at 135.

17 An Ordinance to render certain Marriages Valid 18425 Vict No 11; An Ordinance for regulating Marriages in the Colony of New Zealand 184711 Vict No 7.

18 One dissertation has been produced on the topic: Maureen Hickey "Breach of promise of marriage" (Dip Arts Thesis, University of Otago, 1992).

19 It was not a common action during the twentieth century but there was a strong campaign to repeal the relevant statute. One prominent campaigner for reform argued that "women think they labour under many disadvantages but they certainly have the best of here [in breach of promise actions] and it is the 'dominating male' who is the victim": Doris Meares Mirams Breach of promise and legislation (Press, Christchurch, 1861) at 3. The action was abolished under the Domestic Acts Act 1975, s 5.

20 Rosemary Coombe "'The Most Disgusting, Disgraceful and Iniquitous Proceedings in our Law': The Action for Breach of Promise of Marriage in Nineteenth Century Ontario" (1998) 38 U Toronto LJ 64; Ginger S 
England during the nineteenth century is particularly relevant to the action in New Zealand, as many of these cases were widely disseminated in newspapers published around the Empire. New Zealand editors frequently reproduced these case reports for the enjoyment of their readers. ${ }^{21}$ These cases also include many common elements that are shared with the cases heard in New Zealand during a similar period.

\section{THE ACTION OF BREACH OF PROMISE OF MARRIAGE}

The promise and reciprocal agreement of marriage was considered to be a civil contract. ${ }^{22}$ The civil action of breach of promise was the legal consequence of breaching this contract. While an agreement to marry was a contract, the remedies available were not the same as for breach of a commercial agreement and the parties involved could not be made to honour the contract. Instead, the court could award damages to compensate for the loss of settlement (meaning the value of the lost marriage). In England, actions for breach of promise were initially brought before the Ecclesiastical Courts, with the first antecedents of the action dating back to the sixteenth century. ${ }^{23}$ After the passing of Hardwicke's Marriage Act in 1753, the church courts could no longer compel a celebration of marriage in facie ecclesiae (in the face of the church) whether per verba de presenti (a current agreement of marriage) or per verba de futuro (an agreement to marry in the future). ${ }^{24}$ Consequently, people were left with little option but to take an action for breach of promise in the civil courts. ${ }^{25}$ Gradually the action began to evolve, from its conception in the seventeenth century as simply a contract action through to the nineteenth century when it increasingly became focussed

Frost Promises Broken: Courtship, Class and Gender in Victorian England (University Press of Virginia, Charlottesville, 1995); Saskia Lettmaier Broken Engagements: The Action for Breach of Promise of Marriage and the Feminine Ideal, 1800-1940 (Oxford University Press, Oxford, 2010); Alecia Simmonds "Promises and Pie-Crusts were made to be Broke: Breach of Promise of Marriage and the Regulation of Courtship in Early Colonial Australia" (2005) 23 The Australian Feminist Law Journal 99.

21 Many international breach of promise cases were reported in New Zealand during the nineteenth century. One well-known example was the reporting of Smith $v$ The Earl Ferrers (1846), which is discussed in closer detail at footnote 67: Smith $v$ The Earl Ferrers, Proceedings upon the trial of the action brought by Mary Elizabeth Smith against the Right Hon. Washington Sewallis Shirley, Earl Ferrers, for breach of promise of marriage, London: William Pickering, 1846.Reported in New Zealand in New Zealander (Auckland, 29 August 1846) at 4 (reproduced from the Watchman (London, 25 February 1846)).

22 William Blackstone Commentaries on the Laws of England: In Four Books: Volume 1, Of the Rights of Persons (John Murray, London, 1862) at 441.

23 Martin Ingram Church courts, sex and marriage in England, 1570-1640 (Cambridge University Press, New York, 1987) at 208

24 An Act for the Better Preventing of Clandestine Marriage 175326 Geo II C 33 (UK) s XIII. Otherwise known as Lord Hardwicke's Marriage Act.

25 Frost Promises Broken, above n 20, at 15. 
on injury to the plaintiff and the damages awarded. ${ }^{26}$ It was in this context that Fitzgerald $v$ Clifford was heard.

The civil action provided scorned lovers an avenue not only for compensation for being wronged, but provided a public forum in which they could make their past suitor accountable for their conduct. It was an action that was taken predominantly by women and was usually successful for the plaintiff. ${ }^{27}$ The motivations for taking the action could vary. For all women, however, the impact that a failed engagement could have on their livelihood was a central motive to taking an action of breach of promise. The circumstances around each case varied. For some women, a man had courted them, only to withdraw the proposal at a later date, or in other cases, the engagement carried on for an unacceptable length of time. The circumstances could also be crueller; for example women who had been left with illegitimate children or found that they in fact were the secret lover to a man already with a family. These grounds varied from the banal spat between lovers through to the most cruel and dishonourable of conduct. The cases were often scandalous and as a result were subject to much interest by the colonial public. The reporting of sensational trials was a common occurrence in the colony's newspapers. Breach of promise cases from England, Australia and the United States were regularly published as these cases were of great interest to the reading public. Local cases also generated a great deal of public attention. These cases provided a view into the usually private world of courtship.

A promise of marriage could be expressed in multiple ways. For some couples the promise was made in private, for others the parents played central role in the betrothal and for many a record of the engagement existed in love letters between the pair. How the engagement was expressed had implications for the action of breach of promise. Prior to 1875 when the rules around evidence were reformed in New Zealand, if there were no letters between the couple confirming the engagement, the plaintiff's case had to rest on the conduct of the parties during the engagement. ${ }^{28}$ For example, relatives or employees who had observed the couple would be called to give evidence about whether they considered the pair to be engaged during the period of courtship. The plaintiff's counsel could use seemingly insignificant information such as a servant overhearing the defendant using the plaintiff's Christian name to argue that an engagement was thought to have taken place. This

26 Lettmaier Broken Engagements, above n 20, at 26.

27 Only one of the ten cases heard in New Zealand between 1842-1874 included a male plaintiff: Julius Wenkheim v Hermann Arndt and Marie Arndt SC Dunedin, 18 April 1873 per Chapman J reported in Otago Daily Times (Dunedin, 19 April 1873) at 1 (Supp); (21 April 1873), at 2-3; (22 April 1873), at 1 (Supp). All cases in New Zealand during this period that went to trial resulted in a verdict for the plaintiff with damages. All individuals involved in these cases were Pākeha.

28 Charles M MacColla Breach of Promise, Its History and Social Considerations (Pickering \& Co, London, 1879) at 20 . 
evidence was often speculative but was the only means in which prove an engagement without the necessary documentary evidence. Judges also allowed hearsay evidence to be used in this action.

During the nineteenth century the rules of evidence underwent significant reform. Prior to this reform, the common law ruled that no person could give evidence in an action to which they had a personal interest. Therefore the plaintiff and the defendant in an action for breach of promise of marriage were not able to give evidence during their trial. In England the law of evidence was broadly amended in 1851 to enable persons involved in the action to give evidence before the court. ${ }^{29}$ However, actions for breach of promise of marriage were excluded from this statute and the rules around evidence in this action were not amended in England until 1869. ${ }^{30}$

New Zealand was slower to adopt evidence reform. The process for the reform of evidence took place over several years beginning in 1871, when Parliament began to debate the Evidence Bill. The impact that the legislation would have on breach of promise of marriage cases was a concern. In Parliament, George Waterhouse raised evidence he had seen which suggested that "the passing of that Bill [32 Vict c68] had led to the commencement of a large number of actions for breach of promise of marriage against old people by their housekeepers ... that was one of the characteristics of the breach of promise cases within the last year or eighteen months in England." ${ }^{31}$ Members of Parliament also voiced concerns over the possibility that there would be an increase in the crime of perjury if the law was changed. ${ }^{32}$ The legislation was abandoned on the basis that it would be revisited once the effects of the law had been established in England. The legislation also failed to pass in 1873 and was finally successful in 1875. The Evidence Further Amendment Act, 1875 decreed that any party to an action for breach of promise shall be able to give evidence, provided that it was corroborated by other material evidence. ${ }^{33}$ The result of the passing of this legislation was that it enabled parties directly involved in the cases to give evidence and consequently the evidence admitted in trials became less speculative and more focussed on that of the couple involved.

Most failed engagements did not end up in the courtroom. Most families would have attempted to settle the dispute privately, with very few opting for the court to resolve the issue. The process for bringing the action to court was straightforward. The plaintiff's counsel would ask the Supreme

29 Act to Amend the Law of Evidence 185114 and 15 Vict c 99 (UK), s 2.

30 Actions for breach of promise of marriage were excluded under the original 1851 Act (14 and 15 Vict c 99, s 4). This was reformed in 1869: Evidence Further Amendment Act 186932 Vict c 68 (UK), s 2.

31 New Zealand Parliamentary Debates (New Zealand Government Printer, Wellington, 1871) at 551.

32 Ibid.

33 An Act for further Amendment of the Law of Evidence 187531 Vict No 81, s 3. This statute was based on the English equivalent. 
Court Registrar for a writ of summons; this would order the defendant to appear before the Court. ${ }^{34}$ Alongside the writ, the plaintiff would sign an affidavit outlining the issue for the Court. Before the 1875 evidence reform, this was one way in which the plaintiff could directly engage with the court process. Before the trial commenced, the solicitors for each party would meet with the judge to establish the point of issue. During the trial, the plaintiff's counsel would attempt to establish how the promise of marriage was made and reciprocated. This was shown by using evidence demonstrating that the promise was made and accepted either by word or by action. ${ }^{35}$

A series of defences were used by counsel to exonerate their clients. Some claimed that the plaintiff's bad health or bad character were grounds to end the engagement as the woman would be unfit to carry out the role of wife. Some defendants offered no defence at all, agreeing that they had promised to marry the plaintiff and merely failed to carry through that promise. The most common defence was to simply refuse that a promise of marriage had been made. If there were no letters, no formal declaration of the engagement or any public appearances of the couple together, it became difficult for the plaintiff to prove the existence of the engagement. In the case of Fitzgerald $v$ Clifford, the defendant argued that a promise of marriage was never made to the plaintiff but he was unable to offer any evidence to prove this. A defendant also was unable to use a pre-existing engagement as a valid defence, for a person could not avail themselves of their own wrong. ${ }^{36}$ Therefore the existence of Clifford's original, English engagement could not have been used as a valid defence in this action either.

The amount of damages awarded was decided by the jury. Plaintiffs often sought damages not just for loss of settlement but also the emotional distress caused by the failed engagement. ${ }^{37}$ The amount awarded depended on the circumstances of each case, such as the duration of the engagement, the social standing of the parties involved and the level of the defendant's 'bad conduct'. These factors could ultimately increase or limit the amount of damages awarded. Saskia Lettmair has argued that English juries also took into account the age and physical appearance of the female plaintiffs. When deciding damages the older and less attractive plaintiffs often left with a small settlement or even empty-handed. ${ }^{38}$ There is one possible example of this in the body of New Zealand cases heard before $1875 .{ }^{39}$ Overall, it was a subjective decision for the jury to assess the

34 Court procedure outlined in An Ordinance to confirm certain Rules, Forms and Table of Fees touching the Practice of the Supreme Court 18448 Vict No 1, r 13.

35 Joseph Chitty, John A Russell (ed) A Practical Treatise on the Law of Contracts, not under seal and the usual defences to actions thereon (4th ed, Sweet, Chancery Lane, London, 1850) at 16.

36 Ibid, at 468.

37 Lettmaier Broken Engagements, above n 20, at 48.

38 Ibid, at 53.

39 Sarah Ann Ford v Alexander Telpher, Supreme Court Dunedin, 21 June 1864 per Richmond J, reported in Otago Daily Times (Dunedin, 22 June 1864) at 5. In this case both parties were widowed and of "mature" 
amount awarded; it relied on their sympathy for the plaintiff's circumstances. Was she especially wronged during the affair? Or was she responsible for failed engagement? In an 1870 editorial in the Wanganui Chronicle, the author explored the arbitrary nature of damages asking "Are the jury able to assess outraged feelings? To put a price on upon a broken heart?"40 While the amount awarded could be arbitrary, judges still gave the jury some guidance to ensure that the amount of damages awarded was appropriate and would not impact unfairly on the defendant. ${ }^{41}$

The action of breach of promise generated some strong public views. Unsurprisingly it was not a popular action among men, and criticism of the action was a common feature in the local press during the 1870s. One significant criticism was the gender imbalance of the action. Men very rarely took out proceedings after a failed engagement and consequently there was a very high success rate for female plaintiffs. During the trial the plaintiff was often framed as a victim, due to the supposed hardship they had endured by the break up of their engagement, and juries and judges were often sympathetic. ${ }^{42}$ Newspaper columnists argued that women were better off having the engagement terminated, rather than being forced to live in an unhappy marriage. While this may have been correct in the long term, this argument ignored the vulnerable position that a woman with a failed engagement was in. First, without a spouse, a woman had little financial protection. Second, in a society that judged women on their sexual purity, or perceived lack of it, a failed engagement could have a significant impact on the woman's reputation and in particular her ability to find another suitable husband.

\section{FITZGERALD V CLIFFORD}

The trial of Fitzgerald v Clifford took place over two days during 1846; it was longest trial to be heard by Chapman J during his time as Supreme Court Judge for the Southern District of New Zealand (1844-1851). Emily Fitzgerald sought $£ 2000$ damages for breach of promise of marriage from Charles Clifford. While this was a large amount, it was normal for women to claim substantial damages for the loss of settlement. In his opening address, the plaintiff's counsel, Hugh Ross, argued

age. Telpher apparently decided he would not marry Ford after proposing. While there were some gaps in the plaintiff's case the jury still found for the plaintiff and awarded just one shilling in damages.

40 Wanganui Chronicle (Whanganui, 5 May 1870) at 2.

41 Ellen Brown v David Peter, Supreme Court Dunedin, 16 July 1872 per Chapman J, reported in Otago Daily Times (Dunedin, 17 June 1872) at 4. Chapman J advised the jury that the amount of damages awarded should not "be such as to absolutely ruin the defendant". Peter, a stockman, was ordered to pay $£ 40$ in damages.

42 Gender bias was one of the grounds used in the campaign to abolish the action in England during the late 1870 s. It was argued that as men did not tend to take out actions for breach of promise, it was unfair that women in turn did use the action and were able to secure significant settlements. A bill was introduced to the House of Commons but failed to gain enough support: A Bill to Abolish the Action of Breach of Promise of Marriage 187841 Vict c 1 (UK). 
that Clifford courted Emily for four years, visiting almost daily until April 1846, when the relationship was "broken off" due to his 'other' fiancée agreeing to travel to the colony to be married. There were three key issues that the jury had to agree upon in this case. First, had the defendant promised to marry the plaintiff? Second, was the plaintiff willing, at the time, to marry the defendant (and thereby showing that the engagement was reciprocal)? And last, if these issues were proved, what amount of damages was the plaintiff entitled to recover as settlement?

The Fitzgeralds had very little family in the New Zealand. Emily spent the majority of her time residing with her much younger brother Thomas. She was twenty-seven years old when she immigrated to New Zealand and was under the care of Thomas, who was eighteen at the time of their departure. She also spent time living at her brother John's house, who was also younger than her. The Court heard that during 1842 Clifford began to court Emily. He was a regular visitor to the Fitzgerald household and over time it became apparent that his interest lay primarily with Emily. As Thomas was Emily's guardian and also a friend of Clifford's he questioned Clifford in January 1845 about his intentions with his sister. It was known that Clifford was courting Emily but this was complicated by the fact that it had been recently discovered that he was 'nominally' engaged to a woman in England. Clifford claimed that the engagement was of no importance because she would never travel to New Zealand to carry out the marriage and he would not return to England. From this point, relations between the Fitzgeralds and Clifford became somewhat strained. Charles clearly had an interest in Emily but his intentions remained unclear and, to Thomas, his conduct was questionable and even "ungentlemanly". Over the next eighteen months, Clifford would continue to meet privately with Emily, but his friendship with the family would begin to unravel, culminating with his confession that he would honour his commitment to his original fiancée and the subsequent action for breach of promise of marriage laid against him.

It is unknown exactly when the Fitzgeralds took out legal proceedings against Clifford. The relationship ended in April 1846 and it is likely that the action was laid after June, as the case was heard in the following Supreme Court quarterly sitting in September. ${ }^{43}$ It seems likely that they took this course because of the long, drawn out nature of the failed courtship and length of time it took to resolve. Sending a letter to England and receiving a response could take at least six months due to the irregular mail service. For Emily, this meant that her courtship with Clifford was in a state of uncertainty for a very lengthy period. She was also thirty two years old at the time of the trial, an age which was well over the average for women to marry in the early colony. Her age could have detracted from her ability to find another suitor, which in turn could effect her livelihood - all the more reason for her to seek substantial damages.

Eight witnesses were called to testify for the plaintiff. They included the employees living at the Fitzgerald house, neighbours living on Porirua Road, Emily's two brothers Thomas and John and her

43 During the 1840s the Supreme Court sat quarterly to hear both civil and criminal cases. These sitting took place in March, June, September and December. 
sister-in-law Eliza. These witnesses provided an account of Clifford and Emily's courtship and their thoughts on Clifford's conduct during the affair. The first and most illuminating testimony came from Fitzgeralds' servant, Mary Reid. She lived with Thomas and Emily for ten months over 184445 and possibly had the closest view into the pair's private relationship. She testified that she believed Clifford and Emily were lovers, noting that their visits took place over three or four hours, behind closed doors. She was forbidden to enter without knocking. She stated that "from $\mathrm{Mr}$ Clifford's behaviour - I should think he was on terms of intimacy." 44 She also claimed to have seen them talking closely at church, noting "I know they were lovers because there is something between sweethearts that you cannot help knowing". Four further witnesses all testified to seeing the pair together frequently with it being a common occurrence for Emily to wait for Clifford in the garden. Under the guise of reading she would wait for him to ride up the road, sometimes sitting out there as long as five hours. ${ }^{45}$ These witnesses emphasised that he was the only man to visit Emily alone and that the pair were unaccompanied while these visits were taking place.

While the case directly involved Emily, her brothers had a significant participation in the case too, largely to protect their sister's reputation, livelihood and the family name. The most substantial testimony in the case came from Emily's brothers. Thomas took the stand first, expressing the view that he had initially supported Clifford's relationship with his sister, noting that he was pleased with the union as Clifford was someone he "esteemed". Clifford was a man of good social standing and was a close family friend, an ideal suitor for their sister. As noted, Thomas met with Clifford in early 1845 to question him on his intentions with his sister and to discuss the matter of his English proposal. Thomas demanded that Clifford should cease visiting his sister until the matter was cleared up. He also stated that Clifford and Emily could not make a public declaration of their relationship until Thomas had received written confirmation from England proving that the English engagement was over. It is clear from the testimony that Clifford ignored Thomas's request and continued to meet with Emily.

In addition to Thomas's testimony, there were a selection of letters exchanged between the Thomas and Clifford between January and November 1845 given in evidence. ${ }^{46}$ These letters display the formalities in the exchanges between the men: although involved in tense discussion they still maintained proper decorum and etiquette. The letters discussed past conversations between

44 The term "intimacy" did not necessarily indicate a sexual relationship, rather it referred to the closeness of the pair. The term was also used during the trial to describe the close friendship Clifford had with the Fitzgeralds.

45 Ann Harvey, Thomas Fitzgerald's servant from January-June 1846 deposed to seeing Emily sitting in the garden so that she could be seen from the road. She would often sit from $10 \mathrm{am}-3 \mathrm{pm}$.

46 Chapman J's notebook contains copies of four letters: Thomas Fitzgerald to Charles Clifford, 14 January 1845; Clifford to Thomas, 14 January 1845; [Author unknown], 31 October 1845; Fitzgerald to Clifford, 6 November 1845 . 
the pair about Emily. In the final letter, Thomas again asked for an explanation from Clifford about his intentions towards his sister, as her "immediate protector" he had a right to demand an explanation from Clifford. In person, Clifford refused to give Thomas an answer and responded angrily to Thomas's insinuations about his character, stating "you had better keep your opinion of my conduct to yourself". As relations between the two men continued to deteriorate, John Fitzgerald, the elder of the brothers, become more closely involved with the dispute. Emily had lived with John from time to time and he had had less involvement with the pair's courtship than Thomas. His testimony offered a similar chronology to that of Thomas, albeit a more distanced and less emotive one.

Emily's voice is noticeably absent throughout the testimony of the witnesses. They depose of seeing her waiting for Clifford or quietly seeing the pair together, but the Court very rarely heard of Emily's actual feelings on the matter. John Fitzgerald's testimony is one of the few occasions that she is quoted, where he noted an occasion in November 1845 when she reportedly said to Clifford "there were certain impressions in my mind that you wanted to break this matter off... as far as I am concerned you are free". Despite this conversation Clifford's interest in Emily was renewed from this date and their private visits again increased in frequency. The uncertainty of their courtship came to an end in April 1846 when Clifford received word that Mary Ann Hercy (his original fiancée) would make the trip to the colony to marry him. Instead of confessing to Emily in a proper manner, he visited Eliza Fitzgerald, John's wife, and informed her that his original engagement would be honoured. ${ }^{47}$ Eliza deposed in the trial that "He asked me if I would break the matter to Miss Fitzgerald. I said he had cast a very painful duty on me but as her only female relative I should do so". Emily was reportedly devastated and Clifford left Wellington to stay in the Wairarapa for the interim.

Clifford offered a very brief defence. ${ }^{48} \mathrm{He}$ denied the "promise modo et forma (in manner and form)", contesting the frequency of his visits. He called three witnesses, all whom testified to the irregularity of seeing the pair together. ${ }^{49}$ One of the witnesses, Alexander McIntosh, a labourer who spent substantial time on Porirua Road, deposed to seeing Emily waiting frequently on the side of the road, often without Clifford. This witness was used to cast uncertainty on Emily's reputation, as it was unbecoming for a woman to seen waiting for men. The evidence presented by the plaintiff

47 Eliza Sarah Fitzgerald (nee Christian) (1822-1852). Eliza had travelled to New Zealand with Emily, Thomas and Clifford in 1842. She married John Fitzgerald on her arrival. She was Emily's only female relative in New Zealand and was eight years younger than Emily. Eliza died at age thirty, leaving John Fitzgerald widowed with four young children.

48 Clifford was represented by Alfred de Bathe Brandon, one of the first solicitors to be admitted to the court by Justice Chapman in 1844.

49 The defendant's three witnesses were: William Saunders, Clifford's gardener; William Gill, a carpenter who lived on Porirua Road; Alexander McIntosh, labourer. 
proved that he had never made a public declaration with Emily but this did not necessarily mean that they were not publicly known to be courting. Thomas stated that Clifford had "admitted a positive engagement between my sister and him", not publicly, but while the two men were discussing Emily. As the case was never reported and Chapman $\mathrm{J}$ did not record his closing remarks, it is difficult to gain a sense of his directions to the jury. However, the plaintiff did have a very strong case even though the evidence was largely opinion based with little documentation. The jury found a verdict for the plaintiff and she was awarded 100 guineas. ${ }^{50}$ This was not a large settlement. In later cases, women in similar circumstances were awarded more substantial damages. ${ }^{51}$ It is likely that the jury felt that Emily would be able to find another suitor easily enough or there is the possibility that the jury awarded an amount they felt Clifford could afford, after all many of those adjudicating were close associates, well known to both parties.

The trial seems to have had very little impact on Clifford's reputation in the colony. He went on to have an illustrious political career and became a major land owner in the South Island. This episode remains absent from his biographical entries published since. The case also had no bearing on his original engagement. Mary Ann Hercy was at sea while the trial took place, she arrived in Wellington in January 1847, and the couple married just six days later. ${ }^{52}$ Fortunately for Emily she was able to find another suitor. She married Wellington shipping agent Robert Tyser in September 1849. ${ }^{53}$ Tyser was an early Wellington settler who was prominent in the Wellington mercantile community.

\section{COLONIAL COURTSHIP}

The Fitzgerald $v$ Clifford case exposes some key ideas around notions of courtship in the colony. For women, marriage was a very important stage in their life as their economic and social status depended their choice of husband. Finding a potential suitor could be an arduous time. Macdonald and Porter have written of the uncertainty faced by women during the period of courtship, anxiety caused by "how to behave, how to interpret signals, how to appear polite and sociable but not, heaven forbid, 'forward' or 'encouraging' where encouragement was not

50 The amount of damages was the equivalent of $£ 105$.

51 For discussion of damages awarded in other New Zealand cases before 1875 see footnotes 57, 62 and 63.

52 "Shipping Intelligence" NZSCSG (Wellington, 9 January 1847) at 2. The couple had five children together and remained married until Clifford's death in 1893. HAL Laing and KA Simpson "Clifford, Charles 18131893" (1990) Dictionary of New Zealand Biography <www.dnzb.govt.nz〉.

53 The pair married on 20 September 1849 at "Woodlands", Porirua Road, the home belonging to her brother Thomas: NZSCSG (Wellington 22 September 1849) at 2. Their union would be short lived as Robert died just five years later, leaving Emily with three children. She continued to live closely with her brother Thomas. The two families had relocated to the Hawkes Bay during the 1850s. 
intended". ${ }^{54}$ During the nineteenth century, love increasingly became the central foundation for couples to marry, with families becoming less involved in selecting the woman's potential husband. It is clear from the case that Emily and Clifford had a romantic union, one that was borne from deep affection not family arrangement. However, their relationship was not always compliant with the normal protocols of courtship adhered to by the middle and upper classes ${ }^{55}$ Families, particularly in upper class circles, still played a part in overseeing a couple's courtship, whether chaperoning visits or ensuring both parties maintained the appropriate level of decorum.

Love and courtship were governed by their own set of rules. These rules or social conventions framed the way in which upper class men and women could meet and engage with each other. Single men and women did not tend to meet casually, rather their time spent together was more formal, meeting at a family home or at church but not alone without the knowledge of a woman's guardian. One of the central features of Clifford and Emily's courtship was the frequency of unchaperoned visits shared by the couple. These visits took place while Emily's guardian (Thomas) was working, often away from the eyes of the house's servants. It is clear that Clifford and Emily's courtship was unusual, but so too was the Fitzgeralds' family life. Emily was under the care of her younger brothers, Thomas and John. Her parents were still living Ireland or likely to be deceased; it is unclear how much of a relationship the Fitzgerald children had with their family back home. The consequence of this distance was that Emily did not have the parental guidance and supervision that many other single women in her circle would have had during this time. She was often alone at the house on Porirua Road, which gave her more freedom and independence than many of her peers. She certainly would not have been allowed to wait, visibly on the side of her road for her sweetheart, had she resided with her mother. Clifford was able to come and go while her brother was away and the pair formed a relationship in a less formal manner. These unchaperoned visits may have been disapproved of in England or Ireland but, due to the family's circumstances in the colony, these arrangements were tolerated but not necessarily approved of.

A woman's reputation and respectability was very important in the colony, but this could be threatened by idle gossip. Kristen McKenzie has noted that a respectable woman's life was divided into three distinct stages, the first being "a chaste courtship sanctioned by parental approval". ${ }^{56} \mathrm{~A}$

54 Frances Porter, Charlotte Macdonald with Tui MacDonald (eds) My hand will write what my heart dictates: the unsettled lives of women in nineteenth-century New Zealand as revealed to sisters, family and friends (Bridget Williams Books, Wellington, 1996) at 187.

55 While both parties in Fitzgerald $v$ Clifford were of part of the colonial elite in the colony, their ideas around courtship stemmed from English traditions and cultural norms. This section uses the term "middle and upper classes" in this context because the type of courtship being exhibited directly derives from the English classes. The discussion of courtship and notions of respectability in this article focuses entirely on this social group in New Zealand. It is likely that attitudes towards personal conduct, courtship and premarital sex would have differenced across class in early New Zealand.

56 Kristen McKenzie argues that the first important stage in a woman's life was a chaste courtship. This was followed by two further stages, the second was a legitimate marriage ceremony and the third a lifelong 
single woman's reputation and her value as a potential wife rested on her chastity. ${ }^{57}$ For many women involved in breach of promise of marriage trials in England, premarital sex was a central component to their case. ${ }^{58}$ In New Zealand, however, this does not seem to have been a common feature in the cases heard before $1875 .{ }^{59}$ In Fitzgerald and Clifford, Emily's chastity was never really called into question during the trial. Thomas' servant, Mary, alludes to the fact that she may have been involved in some sort of passionate behaviour with Clifford but this was not central to the evidence used to prove their engagement. For the other cases heard during this period, closeness and intimacy between couples was discussed, but it was very rarely shown to be physical intimacy. ${ }^{60}$

The courtship practices exhibited in this case differ substantially from the type of courtship explored in the existing New Zealand historiography. ${ }^{61}$ While it is an area that has received very little attention, what does exist, is dominated by accounts of courtship through letter writing. For many couples letter writing was a means of maintaining a relationship during periods of absence. It also provided a more intimate, private means of communication for couples. Emily and Clifford do not appear to have written to each other, or at least no letters between the pair were admitted as evidence during the trial. The result of this was that there was a very limited view of the conversations and promises made between Clifford and Emily. This also suggests that letter writing did not play as large a part in their relationship as they did not have to sustain long periods of absence from each other. The inclusion of letters in breach of promise trials changed the dynamic of

faithful marriage. Kirsten McKenzie Scandal in the Colonies: Sydney and Cape Town, 1800-1850 (Melbourne University Press, Melbourne, 2004) at 91.

57 It was not just sexual activity but any physical indiscretion could be called into question. In the case of Knox $v$ Hunt, the defendant broke off the engagement with the plaintiff because of her "improper conduct". He had been told (but had no proof) that Margaret Knox had kissed another man while the pair was courting. Knox was awarded $£ 1300$, the largest amount of damages awarded in the first thirty years of the action in New Zealand. Margaret Knox v William Hunt, Supreme Court Auckland, 17 December 1868 per Arney CJ reported in Daily Southern Cross (Auckland, 18 December 1868) at 6.

58 Frost argues that one quarter of all breach of promise cases in England had sexual activity as a component of the case: Frost Promises Broken, above n 20, at 98.

59 This may have been a reflection of the women who were taking out actions in New Zealand or the type of evidence being employed by counsel, rather than the non-existence of premarital sex in the colony.

60 The exception to this was the case of Carr $v$ Stevenson, which explicitly noted the occurrence of premarital intercourse. The seventeen year old plaintiff was engaged to the defendant and became pregnant. On hearing the news, the defendant recanted his offer to marry her and the family took out civil proceedings against him. Carr was awarded $£ 100$ damages, an amount meant to reflect the seriousness of the defendant's dishonourable behaviour. However, the relatively conservative amount also represented her social status as a daughter of a blacksmith. Isabella Carr v William Stevenson, Supreme Court Dunedin, 7 November 1868 per Ward J reported in Otago Witness (Dunedin 12 December 1868) at 20.

61 Raewyn Dalziel "Making Us One: Courtship and Marriage in Colonial New Zealand" (1986) 19 Turnbull Library Record 7-26; Margot Fry Tom's letters: the private world of Thomas King, Victorian gentleman (Victoria University Press, Wellington, 2001) ch 4. 
trials. In cases where letters were an important form of communication for couples, they form the majority of evidence heard during the trial. Letters could be used to indicate the sincerity and intent of the relationship. However, increasingly newspapers also reported these letters in full for public consumption and they became an important part in the reporting of these trials. ${ }^{62}$

Class was a key component in breach of promise of marriage cases. Predominately the cases brought before the Supreme Court in New Zealand involved people of similar class. Fitzgerald $v$ Clifford was the only case during this period of study that involved two members of the colonial elite. The other cases heard before 1875 all included middle and working class people. Inter-class courtship was shown in some cases heard, as it was relatively common for men to engage in relationships with employees or women who worked in the public sphere, such as bar maids. ${ }^{63}$ There was some anxiety about the potential for the exploitation of inter-class relationships. In the weeks before the Fitzgerald trial, the local newspapers published reports of the high profile English breach of promise case, Smith v Ferrers. ${ }^{64}$ This case involved the daughter of a farmer taking out an action for $£ 20,000$ in damages against the Earl of Ferrers for breach of promise. It was a highly scandalous affair, with the Court finding that the young woman had forged love letters from the Earl in an attempt to orchestrate the action for substantial damages. While this case was extreme, it did emphasise the concerns that some of the public had in relation to the breach of promise actions. In New Zealand, changes to the rules around evidence generated discussion in parliament about the possibility of perjury increasing in breach of promise actions. The fear that women would tell untruths to gain settlements from men became an increasing concern in the latter part of the nineteenth century. This concern began in England and trickled down to the colonies, taking up many a column inch in the local newspapers, with the Bruce Herald commenting that action encouraged "the fair sex to entrap guileless young gentlemen". 65

62 Elizabeth Feeney v John Richardson, Supreme Court Dunedin, 9 April 1872 per Chapman J, reported in the Otago Witness (Dunedin, 13 April 1872) at 9. This case involved a domestic servant and a seaman. The plaintiff sought $£ 250$ damages as the defendant failed to marry her within a reasonable length of time. The Otago Witness published a series of letters showing the progression of the breakdown of the couple's engagement, from apologies for failing to marry her in 1869 , through to his reaction to the court proceedings in 1871 . These letters created a compelling chain of evidence and the plaintiff was awarded $£ 50$ damages for injured feelings.

63 Mary Morrow v John White, Supreme Court Auckland, action laid 31 May 1869 per Martin CJ. Morrow sought $£ 3000$ damages for breach of promise of marriage. This case was settled out of court and the plaintiff received between $£ 300$ and $£ 400$. Daily Southern Cross (Auckland, 14 June 1869) at 3 . The case had had a high profile in the Daily Southern Cross and it was noted that the public would be disappointed that the case would no longer go to trial.

64 Smith $v$ The Earl Ferrers, above $\mathrm{n} 21$.

65 "Are breach of promise actions worth winning?" Bruce Herald (Milton, 11 April 1890) at 6. 
The action of breach of promise raised considerable public concern about the conduct of both men and women. In terms of female conduct, it was thought that taking out the action could challenge a woman's respectability. Women were expected to be kept within the private sphere in the home. However, participation in a trial brought her before the public and into the traditionally male domain of the courtroom. ${ }^{66} \mathrm{~A}$ woman was expected to behave in a more passive manner and maintain her modesty. By taking out an action for breach of promise, she exposed the private details of her life to the very public court room. It was also a substantial gamble for a woman to allow the closest details of her life to be exposed in a trial. A woman's reputation could be left in tatters all for the sake of winning the action.

For men, most breach of promise cases focussed entirely on the conduct of the defendant. For Clifford, his "ungentlemanly" behaviour was consistently called into question by Thomas Fitzgerald. Central to Victorian masculine identity was the idea of being the breadwinner and maintaining a moral family life. During courtship a man was expected to uphold concepts of honesty, responsibility and respectability. A part of this ethos was keeping promises made. Ginger Frost has argued that breach of promise trials were much more difficult for men because there was a set of social conventions they were expected to adhere to, whereas woman had a much more passive role in courtship and their character was not judged so strictly. ${ }^{67}$ While this true in the context of the courtroom, it would be questionable to argue that women were not subjected to the same social rigour as men during courtship. The stark gender bias in the courtroom meant that women were usually perceived as the victim in the action but this could be complicated if the woman was regarded as 'fallen'. Her personal circumstances could ultimately affect the outcome of the case.

\section{CONCLUSION}

In New Zealand, breach of promise cases became increasingly frequent towards the end of the nineteenth century. Local and international cases continued to generate much public attention, with both real and literary examples of the action becoming a common subject matter for colonial readers. These cases gave the public an unrestricted view into the world of failed courtship; exposing private moments and letters within the very public space of the courtroom. The fact that breach of promise cases were part of the public realm from the later decades of the nineteenth century makes the non-reporting of the Fitzgerald case all the more interesting. It was an action that was well-known to readers and the spectacle and scandal of the trials were a popular and frequent part of colonial newspapers. The complete absence of a case report is unusual, particularly as the case was the first of its kind in the colony and involved well-known individuals. It was an important and very detailed action. The substantial coverage it received in Chapman J's notebook is testimony

66 For discussion of women and the male domain of the court room see Bronwyn Dalley "Criminal Conversations: Infanticide, Gender and Sexuality in Nineteenth Century New Zealand" in Caroline Daley and Deborah Montgomerie (eds) The Gendered Kiwi (Auckland University Press, Auckland, 1999) 70.

67 Frost Promises Broken, above n 20, at 9. 
to its contemporary significance. Court reporting was a central part of newspapers in early New Zealand. By refusing to report the case, the newspaper proprietors were protecting the interests and reputation of their associate rather than reporting the important events in the colony.

The case of Fitzgerald $v$ Clifford exhibits how legal sources can be invaluable in exploring aspect of social history. Matters of romance and courtship are often absent from broader studies of marriage and family because these personal aspects are difficult for the historian to explore. Letters and diaries are often the only sources available and discussion of these aspects can be scarce. Cases of breach of promise of marriage explore courtship in a direct way. While the testimony is carefully framed for the judicial setting, these cases often expose private and uncomplimentary details that can be absent from personal manuscripts. The trial transcripts are rich in their discussion of courtship, conduct, honour, gender and class structures. More generally, court records are a source that enable the historian to draw out more detail about specific people and events. From this case we are able to gain a wider view about Charles Clifford, a well known early settler. In his brief biography he is defined by his public duties and described as a "high-bred, courteous, kindly, and considerate English gentleman". ${ }^{68}$ However, his conduct recalled during the breach of promise trial offers a more complex view of Clifford's character. It is not surprising that his personal transgressions went undocumented; utilising court records can be a way to counter this.

We are able to draw a number of conclusions about early colonial society from the evidence given in Fitzgerald $v$ Clifford. It shows the presence of an established elite, one with definite ideas about conduct and etiquette. It also emphasises the closeness of this group and the interconnections between these families and those with influence in the settlement is reinforced by the outcome of the case and the absence of published reports. The case shows that traditional ideas about courtship had been transported to the new colony but not without tension, caused by the reality of living in an isolated and adapting society. And finally this case and the other breach of promise of marriage cases heard before 1875 reinforces the idea that marriage was central to a woman's livelihood. Women risked their reputation and eligibility by taking an action for breach promise of marriage. This action exposed the private details of their courtship, opening them up to criticism of their character in the public courtroom. The risk of taking out an action was offset by the possibility of winning substantial damages. These damages could compensate for the loss of the marriage or more specifically, for the loss of financial security caused by the broken promise of marriage. For women in colonial New Zealand, taking an action of breach of promise was a means to protect their livelihood, in spite of the public exposure.

68 Laing and Simpson "Clifford, Charles 1813-1893", above n 52. 
